\title{
Revitalization of Kitab Kuning at Boarding School in Indonesia Based on Unity of Sciences
}

\author{
M. Rikza Chamami ${ }^{1}$, Muhammad Nurkhanif ${ }^{2}$, Moh. Syakur ${ }^{3}$, Hanik Rosyida ${ }^{4}$ \\ Universitas Islam Negeri Walisongo Semarang, Indonesia ${ }^{1,2,3,4}$ \\ \{rikza@walisongo.ac.id ${ }^{1}$, muhammadnurkhanif@walisongo.ac.id², moh.syakur@walisongo.ac.id², \\ hanikrosyida89@walisongo.ac.id4\}
}

\begin{abstract}
This research focuses on optimalization of Islamic boarding school "pesantren" education. There is one important element that has faded from "pesantren", it is the mastering and understanding of kitab kuning. No more than $15 \%$ who can master the kitab kuning well, especially for students who study in modern pesantren. The author is aware of this condition during the placement test at one of the pesantren YPMI Al Firdaus in Semarang, Central Java, for prospective students "maha santri" who have gotten scholarships from the ministry of religion affairs. So the writer in this case will provide some concepts and ideas in order to revitalize the kitab kuning studying at pesantren based on unity of science with qualitative field research.
\end{abstract}

Keywords: Revitalization; Kitab Kuning; Islamic Boarding School; Unity of Science

\section{Introduction}

Discussing on Islamic education in Indonesia means relating it to boarding school or 'pondok pesantren'. Since the $17^{\text {th }} \mathrm{AD}$, boarding school in Indonesia has developed rapidly. In the context of social change, this institution has been examined as an institution that has big role in society as ethics and social control. More than just an Islamic institution, boarding school in Indonesia means educational institution of Islamic Indonesia. This pedagogics point of view brings boarding school as an educational institution of traditional Islam that aims to understand Islam as characteristics of Indonesian. There are two opinions on history of the existence of boarding school in Indonesia. The first, at the beginning, the concept boarding school is taken over from educational system used by Hindu in Indonesia as the place of teaching Hindu and cadres who spreading it in Indonesia. The second, the idea explaining that boarding school has taken root from 'tarekat' tradition in Islam as a part of Islamic teaching that is well known as 'tarekat' activity.[1, p. 88]

'Pesantren' is traditional Islamic boarding school in Indonesia. This institution focuses on teaching Islam using traditional method that has special rules, administration, and curriculum.[2, p. 47] On the other word, boarding school is an institution of Islamic education that grows up and accepted by society that uses boarding system in which 'santri' accept Islamic teaching trough 'pengajian' system or 'madrasah' under the management leadership of a Kyai that is charismatics and independent in all aspects.[3, p. 87] 
To build a boarding school must fulfill five important aspects. Those five aspects are Kyai, santri, asrama, masjid, and classical Islamic books (kitab kuning)[4, pp. 28-31]. However, boarding school can innovate by adopting the other important elements of education to optimize the implementation of education in boarding school. Based on its characteristics, boarding school can be classified on three models, that are modern, classic (salafi) and semimodern.[5, pp. 224-226] There are many boarding schools that has great alumnus with huge achievements both in exact and non-exact fields. Moreover, some of them has got scholarship to continue their study in the higher stage of education in Indonesia and abroad. This is such a great pride for boarding school.

As the significant development of boarding school, unfortunately there is an important unsure that slowly disappears, which is the tradition of mastering and understanding kitab kuning. This degradation of mastering kitab kuning among santri can be found in modern boarding school. This condition turn more serious in boarding school that is inhabited by university student, such as YPMI Al Firdaus Boarding School, Semarang Jawa Tengah Indonesia. The writer see this condition when following placement test in that boarding school for scholarship awardee from ministry of religious affairs who are the best delegations from entire Indonesia. This is an ironic condition, because santri is usually identical with the capability in mastering kitab kuning. This problem must be resolved as soon as possible because of the urgence of kitab kuning as one of five important elements in building boarding school. Therefore, the writer will give some concepts and idea in revitalizing the study on kitab kuning in boarding school based on unity of science. In this context, the writer will try to give some alternatives on how to study and understand kitab kuning with learning method that is commonly used in boarding schools in Indonesia, which is well known as bandongan dan sorogan method.

Those methods considered effective by using pegon jawa as helping tool and some symbols of Arabic grammar (ilmu nahwu). Nonetheless, the reality shows that the output of both methods is not effective and efficient enough because of using monotone language, which is Javanese language as language used to translate and explain kitab kuning, while not all santri are form java. In this condition, the language used in explaining and translating kitab kuning must be universal language as a standard language for all santri in Indonesia to make them understand the meaning of kitab kuning, both from its word by word translation and understanding the symbol of Arabic grammar (science of language tools) as part of intellectual treasure and wealth of Islamic education and culture in Indonesia. From this, the writer can combine three languages at once, which are Arabic, Javanese and Indonesian language as a form of unity of sciences.[6]

\section{Discussions and Result}

\subsection{Kinds of Boarding School and its Elements}

The great enthusiasm and interest from Indonesian to model and method of education in boarding school brings the emergence of some kinds and types of boarding school in Indonesia as the form of fulfilling the demand and need of development era. Referring to the idea of Manfred Ziemek[7, pp. 77-79], those types of boarding schools in Indonesia and be classified into three groups as following;

Boarding school Type A, is a traditional boarding school. It is a kind of boarding school that still maintain its traditional values. It means that this boarding school did not experience the transformation in its educational system and there is no prominent innovation in the 
pattern of boarding school. This is the boarding school that that is still stand to maintain the tradition of classical boarding school with its Islamic characteristics.[7]

Boarding school Tipe B, that is a boarding school that has physical tools, such as: mosque, house of Kyai, and boarding for santri, especially santri from far district, that functions as studying room. This boarding school is usually a traditional boarding school that has really simple design as the special characteristics of traditional boarding school[7]. Learning system in this type of boarding school is individual (sorogan), bandungan, and wetonan.

Boarding school type $\mathrm{C}$, or so called as salafi boarding school is combined with school institution (madrasah, SMU or vocational school) that is the characteristics of modernization and in Islamic education. However, this boarding school did not neglect the original system of education such as sorogan, bandungan, and wetonan used by Kyai or ustadz.[8, p. 4]. Boarding school type D, is a modern boarding school. This boarding school is opened for public. The characteristics of this boarding school has transformed significantly, both in educational system and institutional elements.[9, p. 27]

Boarding school type $\mathrm{E}$, is a kind of boarding school that does not have institution of formal education, but gives chance to santri to study in formal school outside the boarding. This type of boarding school can be found in salafi boarding school and the number is relatively smaller than the other types. Boarding school type F, or Ma'had 'aly. This type is usually found in Islamic university. Those university students are inhabited in a boarding for certain time with some rules decided by the university. The students staying at ma'had around the university or near from university must obey the rules.

Neglecting the types and kinds of boarding school above, there are important elements that must be noticed to understand more about the pattern of education in boarding school as distinction from the other educational institution. Those important elements are (1) boarding school for santri to stay, (2) santri: students, (3) mosque[10, p. 148]: place for praying and center of activities in boarding school, (4) kyai: figure or name for people who has superiority in religious affairs and charismatics as well, (5) kitab kuning: as main reference in Islamic studies[4]. According to Bull, Kyai does not have an academic title. Moreover, Kyai is a title form society that includes four components; knowledge, spiritual power, noble descent (biological or spiritual), and morality. Besides, barokah is a form of Kyai's power that has strong relation with morality and character.[3]

Santri has two meanings, that are santri who still study in certain boarding school with ustadz, which has role as assistant of Kyai. This is a narrow concept of term santri. The wide meaning of it is people that once studied in boarding school, whether an ustadz or not, or stull staying at boarding school or has graduated. Nonetheless, not all santri are staying at boarding school or dormitory. Some of them are staying around the boarding school and go from their houses to boarding school to study, or so called as "dilaju". They are usually called as santri "kalong".

The continuity to maintain the teaching of kitab kuning cannot be separated from the motivation of santri in studying kitab kuning in boarding school. Because one day they will continue the transmission of studying kitab kuning to the next generation. It means that if santri has no strong will to study kitab kuning, it will be hard to maintain the continuity of studying this classical book in this boarding school. In this context, motivasion[11] is explained as a power to move or encourage santri, both from the self (intrinsic) and from outside the self (extrinsic) to study and maintain this intellectual treasure in boarding school.

Kitab kuning is a prime literature in exploring the main subjects of learning in boarding school. Kitab kuning in PMA No. 18 year 2014 about the unit of education in boarding school is Islamic books written in Arabic language that become the reference of Islamic knowledge 
tradition in boarding school. The method used in boarding school to explore this book or kitab kuning is by translating and understanding the content of kitab kuning, books or manuscript of Islamic knowledge written in Arabic into Indonesian language. This is for making easy the process of transferring Islamic knowledge in boarding school. Kitab kuning is classified into four categories: a) From its content, b) From its level of presentation, c) From the writer's creativity, d) From the method of explanation.[12, p. 335]

From the branches of Islamic knowledge, Nurcholish Madjid explain kitab kuning includes various knowledge's such as: Fiqih, Tauhid, Tasawuf, and Nahwu Sharaf. It also can be concluded that the knowledge concentration that develops in boarding school usually includes not less than 12 kinds of knowledge discipline: nahwu, sharf, balaghah, tauhid, fiqh, ushul fiqh, qawaid fiqhiyah, tafsir, hadits, muthalah al-haditsah, tasawuf, and mantiq.

\subsection{Kitab Kuning and Pegon Letter}

The history of Islamic development in Indonesia, especially in Java, has left some uniqueness until know. Those uniqueness are contained in the treasure of local tradition wisdom and its literatures. One of culture and literature that is still maintained well until now is pegon letter. In simple way, pegon letter is a letter or script written in Arabic letter (hija'iyah)[13, p. 1]. This pegon letter in its use is part of local tradition of Islamic society in Java in transmitting the Islamic teachings trough text. Beside in a form of prose, poem, and canons, those Pegon text is an adaptation work in Islamic teaching that is included in books written by middle eastern Islamic scholars of middle age. The pattern used is developing and translating Arabic text into language understandable by local society (Java).

In Kamus Besar Bahasa Indonesia[14, p. 1011] Pegon means Arabic letter that is used to write Javanese language; or Arabic letter that is lack of symbol of sound (diacritic). The term pegon itself has embedded and becomes of acculturation between Islam and Java. This letter becomes popular and starts to be used widely since the development of Islam in Indonesia especially in Java in century of XVII until XIX.[15] Some historical evidences, such as some works of Islamic intellectuals (kitab kuning) in boarding school, deed of engagement, correspondence, epigraphy, nameplate, even newspaper at the time also used pegon letter.

The existence of Arab pegon in Indonesia has strong relation with the spreading of Islam. It is assumed as one way used by Islamic scholars as an effort to spread Islam. Moreover, this Arabic letter is also used in Indonesian literature. According to Koentjaraningrat, in Javanese literature, some of works are written in Javanese language and by pegon letter or gundul, especially for Islamic Javanese literature,[16, p. 20] and Arabic letter used in Javanese language is called as Pegon letter.[17, p. 89] It is actually not happen in Javanese literature only, but also includes Indonesian literature, because according to Juwairiyah Dahlan, they usually study on Indonesian literature that used this arab letter, even in Malaysia is called as Javanese letter.

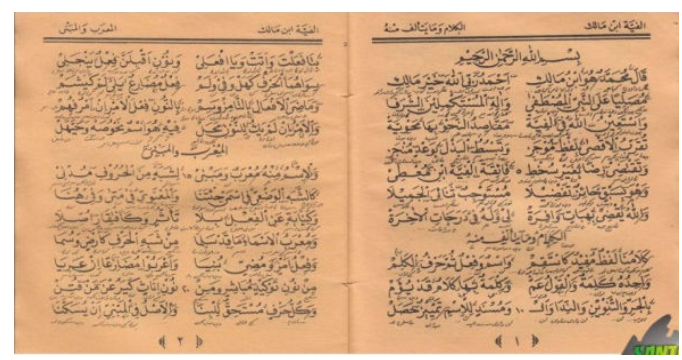

Fig 1. Kitab Kuning with pegon letter 
In boarding school, there are two groups of kitab kuning; the group of books that are taught in curricular and extracurricular activity. Its teaching method is generally divided into sorogan and badongan. The term Badongan means as teaching method in boarding school, which Kyai or ustadz reads, translates, and explaining the content of certain kitab. On the other side, all santri sit together around the Kyai to listen, understand, and write the explanation by letter of Arab-jawa (Arab Pegon). Whereas, method of sorogan is for learning activity, by which santri read in front of Kyai or Ustadz in order to measure their capability in understanding the explained materials before. This method has coherence with curriculum of boarding school as the effort of santri to study actively and seek for the rightness in language and content of book explained by Kyai. Their effort is based on transcript on Arab Pegon that they have studied before.[10]

Both learning methods in boarding school shows the central role of Kyai. It creates the dependence of santri to the reading of Kyai that restricts development to the santri. Meanwhile, kitab kuning is a ready to use product or final truth that has to be accepted and must be taken for granted[18]. Arab pegon is actually the term used by Javanese people, while in Sumatera it is called as Arab-Melayu letter[19]. Therefore, Arab pegon letter or so called as Arab-Melayu letter is a script written in Arabic letter but using local language. Local language means that Arab pegon letter is not only used by Javanese language, but also in west java, it is used in Sundanese language, while in Sulawesi it is used in Bugis language, and in Sumatera it is used in Malayan language.

Hundreds works are written in this pegon letter, such as books of praying, stories, Islamic mysticism, the history of Prophets, and books of historical romance. In the era of Dutch colonialism, before Latin letter are taught in schools, Arabic letters are usually used in sending some letters, even in villages, until the beginning of independence day, there are many people are illiterate in latin letter, but they are literate in Arabic letter. It happens because they must be able to read Arabic letter, both to read al-Qur'an and write letter in local language by Arabic letter.[20, p. 29] According to Denys Lombard, around $1880^{\text {th }}$, Arabic letter is still widely used to write Malayan language and some local languages (such as Aceh language or Minangkabau).[21, p. 164]

Reading or understanding pegon letter is not really difficult. Even though there are many languages and letters before the emergence of pegon letter in Indonesia, its existence has special characteristics that is similar with Javanese letter (Arab Melayu) in Malayan area. Principally pegon letter adopted Arabic letter as Hijaiyah letter. The difference is just there are some additional letter because of habit of Javanese people in using the previous language (honocoroko). Some additional principles in reading and writing is based on modification, and symbols of Arabic grammar in makna gandul as the guide for santri to understand the position of each word in arabic sentence[22].

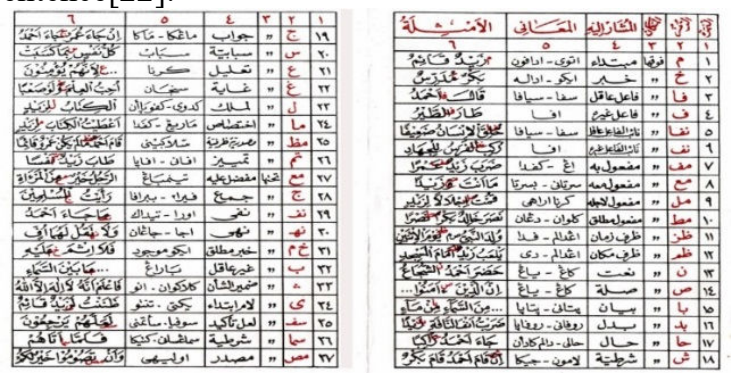

Fig 2. Makna simbol Gandul Pegon 


\subsection{YPMI Al Firdaus Boarding School Semarang and Problem on Mastering Kitab Kuning}

As explained above, there are many types and kinds of boarding school di Indonesia. Some of them are built and developed near from university area, whether Islamic university or the others. Boarding school for university student has bigger challenge than the other types of boarding school. The various background of university students, such as previous education, region, and their usual language are some matters that need to be solved. The writer chose AlFirdaus boarding school as the object of research because this boarding school is not only for general university students, but also for students with special achievements and become scholarship awardees from Ministry of Religious Affairs to continue their study in university.

Al-Firdaus boarding school is an Islamic educational institution under the protection of Pembina Mahasiswa Indonesia Foundation (YPMI). This boarding school is near from university of UIN Walisongo Semarang in Jalan Kedondong Dukuh Duwet RT 02 RW 04 Kelurahan Bringin Kecamatan Ngaliyan Kota Semarang. This boarding school is built in 1993, on $9^{\text {th }}$ Dzulhijjah with the name Al-Firdaus boarding school. The first ground laying is performed by the former of President RI al-magfurlah KH. Abdurahman Wahid (Gus Dur), and announced officially by Rais 'Am Pengurus Besar Nahdlatul Ulama (PBNU) KH. MA. Sahal Mahfuzd and some other figures of Central Java. The existence of Al-Firdaus boarding school is from the idea and initiation of a figure of NU dan PMII, al-marhum H. Umar Farouk that has intention to build a boarding school for university student in Semarang area that is dedicated for the center of forming the young cadres of NU-PMII. Al-Firdaus boarding school is guided by KH. Drs. Ahmad Ali Munir Baasyir, M.S.I. Al-Firdaus boarding school has more than 1000 santri that come from various regions in Indonesia. The result of research explains that the number of santri that is still active until $2020 \mathrm{AD}$ is with following detail:

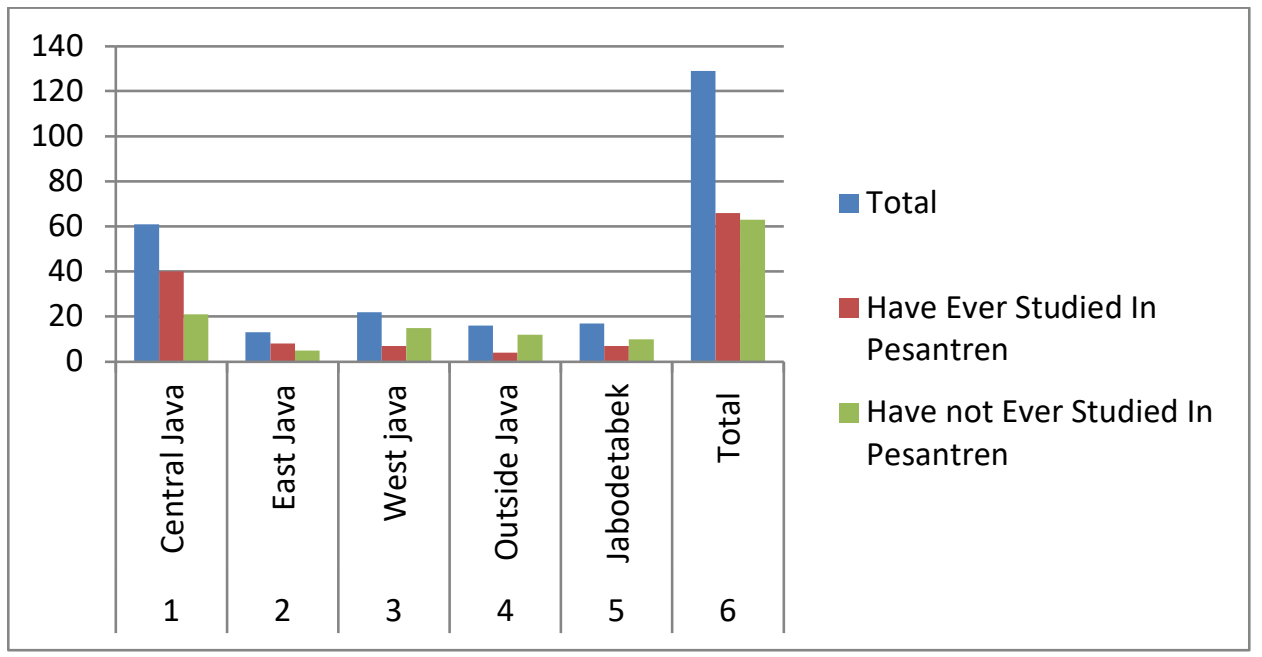

Fig 3. Data of Santri YPMI Al Firdaus Semarang 2020

Curriculum for education and learning in Al Firdaus boarding school uses two systems of studying kitab kuning, which are bandongan and sorogan by dividing the students into 3 classes; 
Table 1. Class and Curriculum in Al Firdaus Boarding School

\begin{tabular}{lll}
\hline \multicolumn{1}{c}{ Class 1 } & \multicolumn{1}{c}{ Class 2 } & \multicolumn{1}{c}{ Class 3 } \\
\hline Qiro'ah Al-Qur'an & Qiro'ah Al-Qur'an & Qiro'ah Al-Qur'an \\
Ta'lim Muta'alim & Imrithi & Al-Wajiz Ushul Fiqh \\
Amtsilah Tashrifiah & Shorof & Kifayatul Atqiya \\
Jurumiyah & Toefl & Sullamu Taufiq \\
Safinah & Arba'in Nawawi & Bulughul Marom \\
Toefl & Adabul Alim wal Muta'alim & Fathul Qorib \\
Irsyadul Ibad & Irsyadul Ibad & Toefl \\
Risalah Mustahadoh & Risalah Mustahadoh & Risalah Mustahadoh \\
& & Irsyadul Ibad \\
& & Sorogan \\
\hline
\end{tabular}

Data research explains that curriculum based on kitab kuning bandongan dan sorogan by using Javanese language as conductor language brings difficulties for santri, especially santri from out of Java. This condition causes only little santri that can master and understand kitab kuning comprehensively, which is not like understanding the translation of kitab kuning only, but also able to implementing knowledge of Arabic grammar such as nahwu and shorof in reading, understanding, and interpreting kitab kuning written in Arabic language.

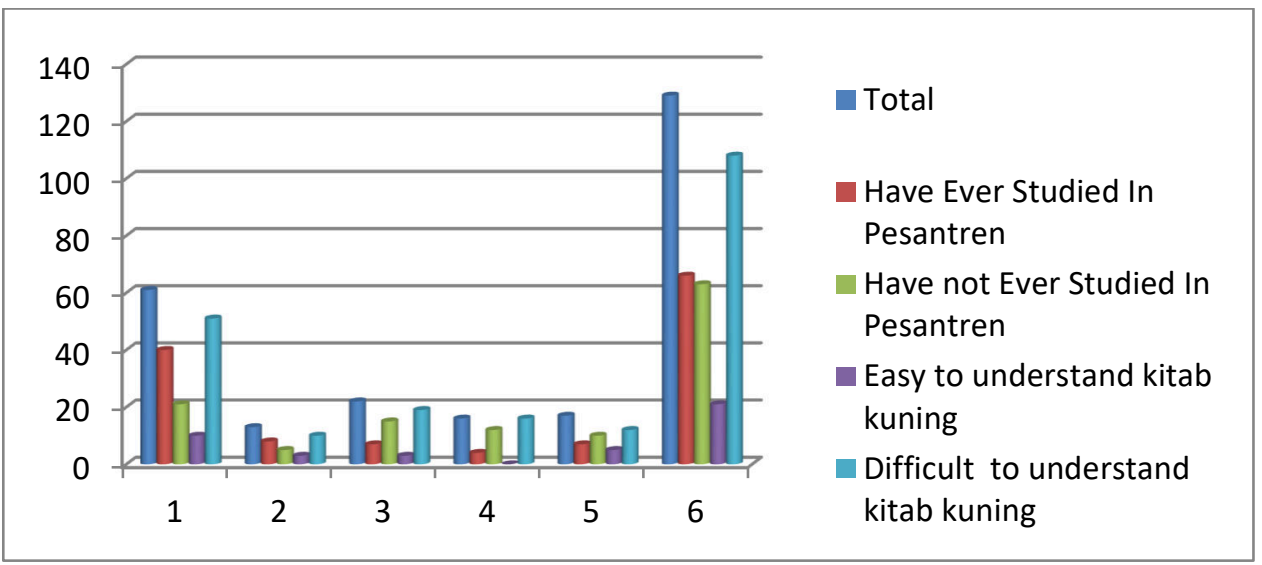

Fig 4. Data of Mastering Kitab Kuning in YPMI Al Firdaus Boarding School

The data above shows that santri who study in YPMI Al Firdaus boarding school almost $90 \%$ of them face difficulties in understanding kitab kuning, especially who come from out of Java. Therefore, this condition needs solution.

\subsection{Reconstruction and Revitalization of Makna Gandul Kiab Kuning Based on Unity of Sciences}

The meaning of unity of sciences in this research is the strategy in implementing the paradigm of unity of science itu. There are three strategies to implement, they are: a. Humanization of Islamic sciences. b. Spiritualization of modern sciences. c. Revitalization of local wisdom. Humanization in this context is to reconstruct Islamic science to make them touch and give solution for factual problems in human life in Indonesia. The strategy of 
humanizing Islamic sciences includes all efforts to combine the Islamic universal value with modern sciences for developing life quality and human civilization.[23, p. 11]

Meanwhile, spiritualization is giving basis of divine values (ilahiyah) and ethics for secular sciences to make sure that basically all sciences are oriented to developing the quality and continuity of human life and the world and not defacing both human and universe. Strategy on spiritualization of modern sciences includes all efforts to build new sciences that are based on the awareness to the unity of sciences that are sourced from God Speech gained from the Prophets, exploration on reason and also the universe.[23]

The last, revitalization of local wisdom is strengthening glorious teachings of the nation. Strategy to revitalize local wisdom consist of all efforts to keep loyal to the glorious teaching of local culture and its development to strengthen national character.[23] In this context, the writer emphasizes on revitalization of local wisdom that is included in makna gandul and symbols of Arabic grammatical sciences that using Arabic language, and then reconstructing them using new model and approach[24], which is by translating it into Indonesian [25] as unifying language. The aim is to make santri who study in this type $\mathrm{E}$ of boarding school can understand and read kitab kuning without being adapted to local language of boarding school.

Table 2. Translation of Makna Gandul Jawa - Indonesia

\begin{tabular}{|c|c|c|c|c|c|c|}
\hline NO & $\begin{array}{c}\text { Simbol } \\
\text { Arab }\end{array}$ & $\begin{array}{c}\text { Simbol } \\
\text { Indonesia }\end{array}$ & Tempat & $\begin{array}{c}\text { Posisi } \\
\text { Tata Bahasa }\end{array}$ & $\begin{array}{c}\text { Arti } \\
\text { Bahasa Jawa }\end{array}$ & $\begin{array}{c}\text { Arti } \\
\text { Bahasa Indonesia }\end{array}$ \\
\hline 1. & 5 & $\mathrm{~m}$ & Di atas & Mubtada & Utawi & Adapun \\
\hline 2. & $\dot{\tau}$ & $\mathrm{kh}$ & Di atas & Khobar & $\mathrm{Iku}$ & Adalah \\
\hline 3. & فا & fâ & Di atas & Fa'il 'Aqil & Sapa & Siapa \\
\hline 4. & ف & $\mathrm{fa}$ & Di atas & Fa'il Ghairuhu & Apa & Apa \\
\hline 5. & نفا & nfâ & Di atas & Naib al-Fail 'aqil & Sapa & Siapa \\
\hline 6. & نف & $\mathrm{nf}$ & Di atas & Naib al-Fail & Apa & Apa \\
\hline 7. & مف & $\mathrm{mfa}$ & Di atas & Maf'ul Bih & Ing & Kepada \\
\hline 8. & مع ع & $\mathrm{m}^{\prime}$ & Di atas & Maful Ma'ah & Sertani & Beserta \\
\hline 9. & مل & $\mathrm{ml}$ & Di atas & Ma'ul Li ajlih & Kerana arahe & Karena (tujuan) \\
\hline 10. & مط & mth & Di atas & Maf'ul Mthlaq & Kelawan & Dengan \\
\hline 11. & ظز & $\mathrm{zhz}$ & Di atas & Dharaf Zaman & Ingdalem & Pada \\
\hline 12. & ظم & $\mathrm{zhm}$ & Di atas & Dharaf Makan & Ingdalem & Di \\
\hline 13. & ن & $\mathrm{n}$ & Di atas & Na'at & Kang & Yang \\
\hline 14. & ص & sh & Di atas & Shilah & Kang & Yang \\
\hline 15. & با & $\mathrm{b}$ & Di atas & Bayan & Nyatane & $\begin{array}{c}\text { Nyatanya } \\
\text { (menjelaskan) }\end{array}$ \\
\hline 16. & بد & bd & Di atas & Badal & Rupane & Rupanya \\
\hline 17. & حان & hâ & Di atas & Hal & Hali & Dalam keadaan \\
\hline 18. & ش & sy & Di atas & Syarthiyah & Lamun & Jika \\
\hline 19 & ج & $\mathrm{j}$ & Di atas & Jawab & Mangka & Maka \\
\hline 20. & س س & $\mathrm{s}$ & Di atas & Sababiyah & Sebab & Sebab \\
\hline 21. & $\varepsilon$ & 'a & Di atas & Ta'liil & Karena & Karena \\
\hline 22. & $\dot{\varepsilon}$ & gh & Di atas & Ghaayah & Senajan & Walaupun \\
\hline 23. & 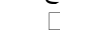 & 1 & Di atas & Lil malik & Kedue & Kepunyaan \\
\hline 24. & 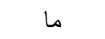 & mâ & Di atas & Ikhtishsaas & Maring & Kepada \\
\hline 25. & مظ & mzh & Di atas & $\begin{array}{l}\text { Mashdariyah } \\
\text { dharfiyah }\end{array}$ & Selagine & Selama masih \\
\hline 26. & تم & $\mathrm{tm}$ & Di atas & Tamyiz & Apane & Apanya \\
\hline 27. & مع & ma' & Di bawah & Maful 'alaih & Tinimbang & Daripada \\
\hline 28. & ج & $\mathrm{j}$ & Di bawah & Jama' & Piro-piro & Beberapa \\
\hline 29. & نفى & nfi & Di bawah & Nafii & Ora & Tidak \\
\hline 30. & نهى & nhi & Di bawah & Nahii & Ojo & Jangan \\
\hline 31. & خ & $\mathrm{khm}$ & Di bawah & Khabar Muthlaq & Iku Maujud & Itu ada \\
\hline 32. & ب & $\mathrm{b}$ & Di bawah & Ghairu 'Aqil & Barang & Sesuatu \\
\hline 33. & $\therefore$ & titik tiga & Di bawah & Dhamir Sya'n & Kelakuan & Bahwa \\
\hline
\end{tabular}




\begin{tabular}{|c|c|c|c|c|c|c|}
\hline NO & $\begin{array}{c}\text { Simbol } \\
\text { Arab }\end{array}$ & $\begin{array}{c}\text { Simbol } \\
\text { Indonesia }\end{array}$ & Tempat & $\begin{array}{c}\text { Posisi } \\
\text { Tata Bahasa }\end{array}$ & $\begin{array}{c}\text { Arti } \\
\text { Bahasa Jawa }\end{array}$ & $\begin{array}{c}\text { Arti } \\
\text { Bahasa Indonesia }\end{array}$ \\
\hline $\begin{array}{l}34 . \\
35 . \\
36 . \\
37 .\end{array}$ & سفى سما & $\begin{array}{c}\text { y } \\
\text { sf } \\
\text { smâ } \\
\text { msha }\end{array}$ & $\begin{array}{l}\text { Di bawah } \\
\text { Di bawah } \\
\text { Di bawah } \\
\text { Di bawah }\end{array}$ & $\begin{array}{l}\text { Lam Ibtida' } \\
\text { La'alla Ta'kiid } \\
\text { Syarthiyah } \\
\text { Mashdar }\end{array}$ & $\begin{array}{c}\text { Yekti } \\
\text { Supaya } \\
\text { Semangsane } \\
\text { olehe }\end{array}$ & $\begin{array}{c}\text { Sesungguhnya } \\
\text { Tentu } \\
\text { Supaya } \\
\text { Ketika } \\
\text { Olehnya } \\
\end{array}$ \\
\hline
\end{tabular}

\section{Conclusion}

The method in teaching kitab kuning implemented in boarding school in transferring knowledge is using mixed methods, which are bandongan and sorogan method. Boarding schools type F, which are boarding school in Indonesia especially in Java that is built in university area or around it needs solution and alternative for santri that come from out of Java to make them able in reading and understanding kitab kuning properly by reconstructing the meaning of symbol gandul pegon by using unifying language, that is Indonesian language. This effort produce new translation on the meaning of symbol gandul pegon based on unity of sciences by emphasizing on revitalization of local wisdom.

\section{Acknowledgements}

The authors would like to thank The Faculty of Education and Vocatioal of Walisongo Islamic University, the Faculty of Syari'a and Law of Walisongo Islamic University, The Faculty of Ushuluddin and Humenities of Walisongo Islamic University, The Faculty of Ushuluddin and Humenities of Walisongo Islamic University, a place for writers to learn and develop science. Second, the author would like to thank LP2M UIN Walisongo Semarang for organizing this event and making this paper published.

\section{References}

[1] A. Muthohar and N. Anam, Manifesto Modernisasi Pendidikan Islam \& Pesantren. Yogyakarta: Pustaka Pelajar, 2013.

[2] A. Nurhayati, Kurikulum Inovasi: Telaah terhadap Pengembangan Kurikulum Pendidikan Pesantren. Yogyakarta: Teras, 2010.

[3] R. A. Lukens-Bull, Jihad ala Pesantren: dimata Antropolog Amerika. Yogyakarta: Gama Media, 2004.

[4] Z. Dhafier, "Tradisi Pesantren: Studi tentang Pandangan Hidup Kyai." LP3ESW, Jakarta, 1982.

[5] A. S. Zarkasyi, Langkah Pengembangan Pesantren dalam Rekonstruksi Pendidikan dan Tradisi Pesantren Religiusitas Iptek. Yogyakarta: Pustaka Pelajar, 1998.

[6] I. Marzuki and Z. S. Rusmono, "How to Develop Blended Learning Educational Evaluation Courses Islamic Religious Education Study Program," Univers. J. Educ. Res., vol. 8, no. 3A, pp. 24-34, Mar. 2020, doi: 10.13189/ujer.2020.081404.

[7] M. Ziemek, Pesantren Dalam Perubahan Sosial. Jakarta: P3M, 1986.

[8] S. Prasijo, Sejarah Pertumbuhan dan Perkembangan lembaga-Lembaga Pendidikan Islam di Indonesia. Jakarta: Grasindo, 2001. 
[9] S. Nizar, Sejarah Pendidikan Islam: Menelusuri Jejak Sejarah Pendidikan Era Rasulullah Sampai Indonesia. Jakarta: Prenada Media Group, 2007.

[10] A. Mughits, Kritik Nalar Fiqh Pesantren. Jakarta: Kecana Prenada Media Group, 2008.

[11] L. Boström and G. Bostedt, "What about Study Motivation? Students' and Teachers' Perspectives on What Affects Study Motivation,” Int. J. Learn. Teach. Educ. Res., vol. 19, no. 8, pp. 40-59, Aug. 2020, doi: 10.26803/ijlter.19.8.3.

[12] S. A. Siradj, Pesantren Masa Depan. Cirebon: Pustaka Hidayah, 2004.

[13] Kromoprawiro, "Kawruh Sastro Pegon,” Madiun, 1867.

[14] J. . Poerwadarminta, Kamus Umum Bahasa Indonesia, XII. Jakarta: Balai Pustaka, 1991.

[15] A. Salim, "Majmu'at al-Syari’at al-kafiyat li al-`Awam Karya Kyai Saleh Darat (Suatu Kajian terhadap Kitab Fiqh Berbahasa Jawa Akhir Abad 19)," IAIN Syarif Hidayatullah, Jakarta, 1995.

[16] Koentjaraningrat, Kebudayaan Jawa. Jakarta: Balai Pustaka, 1994.

[17] A. Chaer, Linguistik umum. Jakarta: Rineka Cipta, 1994.

[18] Maimunah, N. Ibrahim, S. Muslim, and J. Jarudin, "The Influence of Instructional Models and Learning Styles on the Ability to Read to Understand," Univers. J. Educ. Res., vol. 8, no. 3A, pp. 42-47, Mar. 2020, doi: 10.13189/ujer.2020.081406.

[19] A. Mughits, "Melihat Palembang dari Naskah Kuno," Kompas, Sep. 2003.

[20] J. Dahlan, Metode Belajar Mengajar Bahasa Arab. Surabaya: Penerbit Al-ikhlas, 1992.

[21] D. Lombard, Nusa Jawa: Silang Budaya Jilid I. Jakarta: PT. Gramedia Pustaka Utama, 2000.

[22] S. Fareh, N. I. Jarad, and S. M. Yagi, "How Well Can Arab EFL Learners Adequately Use Discourse Markers?," Int. J. Arab. Stud., vol. 20, no. 2, Jul. 2020, doi: 10.33806/ijaes2000.20.2.4.

[23] T. P. C. F. U. O. S. A. H. E. M. (Cushem) Universitas Islam Negeri Walisongo Semarang, Pedoman Implementasi Unity Of Science Dalam Tri Dharma Perguruan Tinggi Universitas Islam Negeri. Semarang: UIN Walisongo, 2018.

[24] L. I. Berezovska, G. D. Kondratska, A. A. Zarytska, K. S. Volkova, and T. M. Matsevko, "Introduction of New Forms of Education in Modern Higher and Vocational Education and Training," Int. J. High. Educ., vol. 9, no. 7, p. 107, Aug. 2020, doi: 10.5430/ijhe.v9n7p107.

[25] W. Adila and T. N. Ma'mun, "Knowledge and Use of Grammar among Indonesian Second Language Learners of Arabic: Focus on Grammatical Gender Agreement," Univers. J. Educ. Res., vol. 8, no. 2, pp. 709-722, Feb. 2020, doi: 10.13189/ujer.2020.080245. 